\title{
1 \\ Contextualising the Bounty in Pacific Maritime Culture
}

\author{
Jean-Claude Teriierooiterai \\ Independent Researcher and \\ Member of the Tahitian Academy
}

As described in the Introduction, there have been many narratives written and filmed - about the Bounty. Historical sources are mainly British, and events have been presented mostly from a British perspective. This chapter ${ }^{1}$ sheds a somewhat different light on Bounty narratives, coming from the perspective of indigenous Pacific Islanders - the perspective of those who stand on 'the other side of the beach', as Greg Dening famously put it. It examines the interactions between European explorers and Pacific Islanders since first contact and, through a close study of late 18th-century Pacific maritime culture and heritage, compares British and Polynesian maritime cultures around the time of the Bounty. The aim is to contextualise the Bounty from a Polynesian perspective and to give voice to the Pacific Islanders of the past: to those who have long been thought of as 'little'.

\footnotetext{
1 Translated into English by Sylvie Largeaud-Ortega and Meredith Wilson.

2 Greg Dening, 'Writing, Rewriting the Beach: An Essay', in Alun Munslow \& Robert A Rosenstone (eds), Experiments in Rethinking History, New York \& London, Routledge, 2004, p 54.
} 


\section{First European and Polynesian encounters: How the Europeans established their reputation as slayers of men}

\section{The Spaniards' first dramatic landfinding}

European explorers were constantly amazed by the diversity of the central Pacific islands. Within a maritime area amounting to one-third of the globe's surface, they encountered expansive, towering islands where water flowed from mountains in abundance; and small, ring-shaped, semi-desert sand atolls. Some islands, such as Tahiti, were crowded with inhabitants. According to Tupaia - the Tahitian priest who sailed with James Cook in 1769 - Tahiti had an estimated population of 200,000. ${ }^{3}$ The discovery of people on the islands of the Pacific differed from the experience of European navigators exploring the islands of other large oceans - such as the Azores and Madeira in the Atlantic Ocean or the Mascarene and the Seychelles in the Indian Ocean - which were uninhabited. It is more than likely that the European explorers who first ventured into the Pacific Ocean expected to find similarly uninhabited islands.

In 1521, Ferdinand Magellan became the first European to cross the Pacific and the first to encounter the islands of Polynesia. He came across the two tiny atolls of Pukapuka (Isla de los Tiburones) in the eastern Tuamotu, and Flint (Isla de San Pablo) in the Line Islands, ${ }^{4}$ both of which appeared to be uninhabited and devoid of evidence of prior settlement. Pukapuka most likely remained uninhabited because it lies at the isolated eastern tip of the Tuamotu Islands and is the last landfall before South America. ${ }^{5}$

The Dutch navigators Jacob Le Maire and Willem Schouten came across Pukapuka atoll in 1616, 95 years after Magellan. While they did not report seeing any inhabitants during their visit, they sighted three dogs on the shoreline. The presence of dogs suggests that people had visited the atoll after Magellan and, therefore, that the Polynesians were continuing to undertake long-distance inter-island voyaging until relatively recently. Magellan eventually made landfall in Guam in the Mariana archipelago

3 The current population of Tahiti is no more than 172,000 people.

4 Philippe Mazellier, Eric Monod, Bengt Danielsson \& Marie-Thérèse Danielsson (eds),

Le Mémorial Polynésien, vol 1, 1521-1833, Papeete, Éditions Hibiscus, 1978.

5 Most Polynesian islands lie between the equator and the Tropic of Capricorn. 
of Micronesia, marking the first European-Pacific Islander encounter. In 1526, five years after Magellan's voyage, the Portuguese explorer Jorge de Menezes approached New Guinea from the west, naming it the Islands of Papua (Ilhas dos Papuas). ${ }^{6}$ Less than 30 years later, in 1555, Juan Gaetano, a Spaniard, is thought by some to have discovered the Islands of Hawai' $i$, and therefore to be the first European to have encountered Polynesians. ${ }^{7}$ A lack of evidence has led to this claim being strongly contested by historians, and Cook is still regarded as being the first Westerner to discover Hawai'i.

The first known encounter between Europeans and Oceanians of Austronesian origin occurred off the Nui atoll in the Tuvalu archipelago, during the first Pacific voyage of Álvaro Mendaña in January 1568. Although the Tuvalu Islands are Polynesian, the Nui atoll was inhabited by Micronesians. ${ }^{8}$ It seems that the Spaniards were not curious explorers, however, and sailed on, merely observing the gesticulating Islanders from their ships as they passed.

Mendaña later reached the Solomon Islands in Melanesia. During a sixmonth stay, the Spaniards wrote numerous descriptions of the archipelago's inhabitants. As might be expected, their reports were strongly influenced by the racial and religious prejudices of the time. ${ }^{9}$ The Spanish agenda in the region was to convert the indigenous peoples to Catholicism, to enslave them and to harvest their gold. The islands were allegedly where King Solomon's fleet had found gold - hence the name given to the archipelago. The Spanish visit involved considerable miscommunication with the Islander communities. There were no religious conversions or enslavements amongst the Islanders, and the Spaniards were refused permission to explore for gold. The Islanders baulked at selling their pigs and forbade the Spaniards access to water sources. The Spaniards did

6 Non-Austronesian Papuans have inhabited the islands and the region for at least 30,000 years and are the earliest inhabitants of the Pacific; Austronesian-speaking communities only joined them 3,500 years ago, which is relatively recent on the scale of human history. See Peter Bellwood, Man's Conquest of the Pacific: The Prehistory of Southeast Asia and Oceania (Auckland, William Collins Publishers, 1978, p 47). See also JHF Sollewijn Gelpke, On the Origin of the Name Papua (Leiden, Kitlv, 1993).

7 The Polynesian Triangle spans from Hawai' $i$ in the north, to Rapa Nui/Easter Island in the east and Aotearoa/New Zealand in the south-west. On the European discovery of Hawai $i$, see Oliver L Douglas, The Pacific Islands (Honolulu, University of Hawai'i Press, 1989, p 45).

8 Micronesian languages are usually part of the Pacific branch, which also includes Polynesian and Melanesian languages. Only the speakers of the Pacific branch of Austronesian may be considered genuine Oceanians, linguistically speaking.

9 Annie Baert, Le Paradis Terrestre, un mythe espagnol en Océanie, Les voyages de Mendaña et de Quirós 1567-1606, Paris, L'Harmattan, 1999. 
not understand that these resources were strongly ritualised among the Solomon Islanders and subject to stringent taboos. The visitors accused the Islanders of being cannibals, and violent clashes ensued. The endurance of the Spaniards eventually waned:

[T]welve [men] were killed in clashes with the natives, ten of whom were attacked and, it is argued, eaten when fetching water at Guadalcanal on 27 May 1568: they were found 'in pieces, some without legs, others without arms, others without heads; all had their tongues cut out, and they had been ripped off their teeth. Those who had not been decapitated had their skulls open, and their brains eaten off ...', one of their terrified companions reported. It appears from the various testimonies that the many skirmishes and inevitable retaliations killed about 80 of the native islanders. ${ }^{10}$

Mendaña decided to sail back to Peru, hoping to return later with more resources and stronger armed forces. On his way home, he caught a glimpse of the Marshall Islands and Wake Island in Micronesia.

Mendaña's second attempt to colonise the Solomon Islands, in 1595, proved a turning point in the history of European-Polynesian encounters. It revealed to the European world the existence of the Polynesian people, and the existence of a hitherto-unknown fruit: that of the breadfruit tree, or Tahitian ' uru - a key feature in the history of the Bounty. Mendaña was on his way to the Solomon Islands when, in the late afternoon of $21 \mathrm{July}$, he sighted an archipelago of mountainous islands. He named it the 'Marquesas de Mendoza' in honour of the wife of the viceroy of Peru. On landing, for the first time in history, a European was facing a Polynesian. It was a shock. Imagine countless warriors, a head taller than the Spanish sailors, brandishing huge clubs, tattooed from head to foot, intrinsically intrepid and inquisitive, clambering aboard the ship and unabashedly snatching whatever they fancied. Muskets were soon firing. The massacre at Tahuata was reported in Spanish journals, as cited by Annie Baert:

10 '... douze (hommes) avaient péri dans des heurts avec les indigènes, dont dix furent attaqués et, dit-on, mangés, lors de la corvée d'eau à Guadalcanal du 27 mai 1568 : on les retrouva "en morceaux, certains sans jambes, d'autres sans bras, d'autres encore sans tête ; tous avaient la langue coupée, et on leur avait arraché les dents. Ceux qui n’avaient pas été décapités avaient le crâne ouvert, et on leur avait mangé la cervelle ...", rapporta, épouvanté, un de leurs compagnons. Il ressort des différents témoignages que les nombreuses escarmouches et les inévitables représailles firent environ 80 morts chez les indigènes.' (Annie Baert, 'Alvaro de Mendańa (1542-1595), un explorateur du Pacifique sud au destin tragique', Île en île, June 2003). 
The fact is that different clashes occurred for several reasons - mainly for the soldiers' fear at being largely outnumbered by the natives, as revealed by this anecdote: '... the camp master and two soldiers [left by boat]. Many Indians, approaching on board their canoes, surrounded them and, in order to ensure their own safety, our men killed a few'. As for the Marquesans, they seemed utterly impervious to fear, despite the Spaniards' attempts at arousing it through deliberately fierce acts, such as slashing the bodies of three musket victims with swords and exposing them on shore. According to Quirós, their visit to this island caused the death of 200 Indians, but a detailed survey of the various skirmishes estimates the actual Marquesan death toll between 25 and $70 .{ }^{11}$

Captain Pedro de Quirós, Mendaña's chief pilot, also reported that during the visit some Marquesan women offered themselves to the Spaniards, whose 'hands feasted'. ${ }^{12}$ French explorer Louis-Antoine de Bougainville famously recalled a similar interaction between foreign men and local women 171 years later in Tahiti, another Polynesian island.

Quirós was the first to mention the fruit of the breadfruit tree, which he observed in Tahuata. The Spaniards did not record the fruit in the Solomon Islands during their first expedition. As discussed in more detail below, breadfruit was the staple food of the Marquesans and of most Eastern Polynesians. Called mei (Artocarpus altilis) by Marquesans, the fruit attracted Quirós' attention: he found it 'to his taste' as well as 'healthy and of high value'. ${ }^{13}$ He learned that fermented mei, called popoi, was a favoured food of the Polynesians when they were out at sea, because it could feed the crew of a double canoe, around 10 people, for several months. Unfortunately, Quirós did not include breadfruit in his own crew's menu and, later in the voyage, the Spanish sorely lacked food after precipitately leaving the Santa Cruz Islands - where breadfruit grew bound for the Philippines (see below).

11 'Toujours est-il que se produisirent différents heurts, pour plusieurs raisons, dont la principale fut la peur que les soldats éprouvèrent devant la supériorité numérique des indigènes, comme le révèle cette anecdote : “... le maître de camp et deux soldats [partirent en chaloupe]. Beaucoup d'Indiens, s'approchant sur leurs canoës, les encerclèrent et, pour garantir leur sécurité, nos hommes en tuèrent quelques-uns". Cette peur, que les Marquisiens ne semblaient pas éprouver le moins du monde face à eux, ils voulurent la leur inspirer par des actes délibérément effrayants, comme lorsque les corps de trois victimes des arquebuses furent tailladés à l'épée et exposés sur le rivage. Bien que selon Quirós, cette escale ait causé la mort de 200 Indiens, si on reprend le détail des différentes escarmouches, on peut estimer le bilan réel entre 25 et 70 morts marquisiens.' (Baert, 2003, p 9).

12 Baert, 2003, p 9.

13 Baert, 1999, p 230. 
Back in Peru, in a report addressed to King Philip II, Quirós highly recommended this fruit, which he described as 'grande y muy buena'. And - most appealing to Bounty aficionados - Quirós tried to convince the Spanish king to establish a new expedition specifically to fetch the countless resources he had discovered in the Marquesas. The king was apparently not convinced of the merits of this proposal. ${ }^{14}$

Following the discovery of the Marquesas Islands, encounters between Europeans and Polynesians intensified. Each European explorer who sailed across the Pacific took to his credit the discovery of one or several islands up until 1816. ${ }^{15}$ Those islands number in the thousands, and span an area roughly 100 million square kilometres. All these islands were either inhabited or had been at some point, such as Pitcairn (see Molle \& Hermann, Chapter 2). Gradually, Europeans began to question how the Pacific came to be inhabited. What were these people doing on these tiny islands in the middle of the Pacific? Who were they? How had their forebears managed such vast ocean crossings?

After visiting the Marquesas, Mendaña sailed westward, without stopping, passing the Polynesian atolls of Pukapuka in the Cook Islands and north Niulakita in the Tuvalu archipelago. He then discovered the island of Nendo, which he named Santa Cruz - a name that was later applied to the whole archipelago. Here Mendaña once again encountered Polynesians. ${ }^{16}$ Relations between the Islanders and the Spanish were, as usual, initially peaceful until the Spanish opened fire with their muskets. They killed Malope, the Polynesian chief of Nendo, which sparked endless trouble. Mendaña died a month later from malaria, along with about 40 of his crew, and the Spaniards eventually left the island. Under the command of Quirós, the survivors headed for the Philippines. Approximately 50 sailors starved to death during the 12-week journey. The "uru, fermented the Polynesian way, might have saved them, if only the Spanish navigators had embraced the preservation practice of the Marquesas. Let it be noted that, when they left Tahiti, neither the crew of the Bounty, bound for the West Indies, nor the man-of-war Pandora, heading for England, appear to have had fermented 'uru on board either.

14 Baert, 1999, p 231.

15 Otto von Kotzebue discovered Tikehau in 1816.

16 Polynesians lived together with Melanesians on those islands. The two communities sometimes lived on islets that were only a stone's throw from one another, but they were fiercely attached to their idiosyncrasies. 
In 1605, Quirós voyaged in search of Terra Australis - the great mythical southern landmass imagined by geographers - in order to take possession of it on behalf of the King of Spain. What he discovered first was Henderson and Ducie, two of the Pitcairn Islands, which he named San Juan Baptista and Puesta Luna. While Quirós registered both islands as uninhabited, recent archaeological research suggests that Henderson was settled by Polynesians from the 10th to the 16th centuries (see Molle \& Hermann, Chapter 2). ${ }^{17}$ Quirós may, therefore, have arrived just after the island was abandoned. Recent research also reveals that the nearby island of Pitcairn had been occupied during the same period. What happened to the people who lived there?

On 10 February 1606, Quirós' fleet arrived at the large Hao atoll, where the first encounter with Pa umotu Islanders took place. ${ }^{18}$ For once, the encounter was peaceful, with gifts exchanged. This atoll's inhabitants must have as yet been unaware of the fatal encounter with the Marquesas a decade earlier.

Quirós' next short visit was at Rakahanga (northern Cook Islands). The lack of fresh water on the island brought his thirsty fleet only temporary solace. While attempting to reach the Santa Cruz Islands, Quirós discovered Taumako - an island of the Duff group located 140 kilometres from Nendo. It was also inhabited by Polynesians from the outliers (i.e. islands outside the Polynesian triangle inhabited by Polynesians who migrated there around a thousand years ago, as in New Caledonia, Vanuatu, Papua New Guinea and the Solomon and Caroline islands). Tumai, their leader, knowing of the Spaniard's fearsome reputation - having heard of their muskets and of Malope's death a decade earlier - did his best to placate them. Responding to Quirós' enquiries about Terra Australis, he revealed the existence of an archipelago of more than 60 islands, ranging from the north-west to the south-east of Taumako. ${ }^{19}$ The Spaniards immediately set sail again and arrived off the island of Santo (northern Vanuatu), which they took for the northerly tip of the sought-after southern continent. Quirós tried to settle there but, faced with the hostility of the Islanders and disloyal behaviour from his own officers and sailors, he decided to head home.

17 Patrick V Kirch, 'Polynesia’s Mystery Islands', Archaeology, no 41, vol 3, 1988, pp 26-31.

18 Pa umotu: inhabitant of the Tuamotu Islands.

19 Pedro Fernandez Quirós, Histoire de la découverte des régions Australes, Iles Salomon, Marquises, Santa Cruz, Tuamotu, Cook du Nord et Vanuatu, traduction et notes de Annie Berat, préface de Paul de Deckker, Paris, L'Harmattan, 2001. 
Several indigenous Islanders were taken from Taumako to be 'educated' in Catholicism in Peru. One of them, who was given the Christian name of Pedro, soon learned enough Spanish to provide valuable evidence about contemporary Polynesian voyages. For instance, he told the Spaniards that a canoe from Vaitupu in the Tuvalu Islands had come to rest in Taumako and that, out of a crew of about 50 people, 10 had survived, including three women. This confirmed that Polynesian women voyaged with men in the traditional ocean-going canoes. Pedro had encountered Polynesians from Tuvalu before; the last time was when a large double canoe sailed from Vaitupu to Sikaiana (500 kilometres north-west of Taumako) with 110 passengers on board..$^{20}$ The Tuvalu voyagers reported sighting European ships off Nui, 1,200 kilometres east of Taumako. This was presumably Mendaña’s fleet from his first voyage 38 years earlier in 1568 .

After the Spanish, the Dutch began to explore the Pacific. They turned out to be more curious, but just as disrespectful, of Pacific Islanders.

\section{The Dutch cross a canoe in the middle of the ocean}

In 1616, 15 years after the Spanish, the Dutch navigators Jacob Le Maire and Willem Schouten ventured into the Tuamotu archipelago. After sighting three dogs on Pukapuka, the Dutch proceeded to find other atolls such as Takapoto, Ahe, Manihi and Rangiroa. Throughout their voyage, they were struck by the Islanders' keen interest in iron, nails and bolts. It may safely be conjectured that virtually all the Pa'umotu had heard from the Hao Islanders about the alien metal, and iron was a sought-after commodity in the islands where it did not previously exist. Nails were traded among Pacific Islanders and trade in iron was conducted before recorded European contact. According to Robert Langdon, a Spanish caravel, the San Lesme, sank off Amanu in 1526 and the iron from the ship may have been traded in the archipelago and beyond, presumably as far as Tahiti. ${ }^{21}$ The Tahitians were already using the word 'auri for the metal when the English arrived there in 1767.

20 Matthew Spriggs, 'Les éclats du triangle polynésien', in Serge Dunis (ed), D'île en île Pacifique, Paris, Klincksieck, 1999, p 38.

21 Robert Langdon, The Lost Caravel, Sydney, Pacific Publications, 1978. 
The Dutch then headed west without deviating from their latitude, like all European explorers of the time. After several days at sea, they came across a double canoe in a remote part of the ocean. The canoe's occupants were travelling between Tonga and Samoa. The contemporary sketches of the vessel indicate that it was a tongiaki, a Tongan double canoe, which could carry several dozen people. The lateen sail on these fast vessels appears, at over 20 metres long, disproportionately large. Perplexed by the presence of the craft in the middle of the ocean, the Dutch intercepted it to take a closer look. When the Polynesian navigators ignored their summons, the Dutch opened fire, killing and injuring several people on board. The survivors jumped overboard. Once the canoe was at a standstill, the Dutch examined it more closely and made sketches before sailing away. Those survivors, who were able to return to the canoe, set sail again and, no doubt, decided to reach the nearest land, the islands north of Tonga, where they could tell their misadventure. This is precisely where the Dutch were heading. The assault was bound to have a serious impact on later encounters between the Islanders and Europeans.

Two days after their attack on the tongiaki, Le Maire and Schouten landed at Tafahi Island in the extreme north of Tonga. The tongiaki survivors must have still been at sea, and the news of the attack had probably not yet reached Tafahi. Le Maire sent a few men ashore with trinkets, which were well received. The Dutch found that, while the Tongans would grab whatever they fancied, they expressed a particular interest in nails. Did the Tongans already know about nails? It is highly likely that the gifts of previous explorers had travelled as far as northern Tonga.

The next day, the Dutch headed to Niuatoputapu, an island visible from Tafahi. To their surprise, a fleet of canoes was awaiting them and launched a fierce attack, but the Dutch managed to ward them off with their muskets. The next day, the island's chief refitted his naval force with 23 double canoes and 45 outriggers, and attacked again. The Dutch fired three cannons to resist their assailants and then sailed away. What caused this sudden change of attitude? Had news of the tongiaki survivors reached Niuatoputapu before the Dutch arrived? The chief of Niuatoputapu was certainly prepared to attack, having brought together numerous canoes and put them in order of battle.

The day after the mutiny on the Bounty, 180 years later, Captain William Bligh and 18 loyalists landed their overcrowded long boat at Tofua, one of the Ha'apai Islands. This group of islands in northern Tonga was the 
closest to where the tongiaki had been attacked. When the Tofua Islanders saw these scruffy, under-armed white men approach their shores, they knew how dangerous they could be, for their elders had passed on the tale of the tongiaki onslaught.

Ten years before the Bounty events, James Cook's visit in 1779 had also demonstrated just how dangerous Europeans could be:

As George Gilbert, one of his midshipmen, remarked, during this visit Cook punished the Tongans in a manner rather unbecoming of a European, viz by cutting off their ears; fireing at them with small shot; or ball as they were swimming or paddling to the shore; and suffering the people to beat them with the oars; and stick the boat hook into them; wherever they could hit them. ${ }^{.22}$

Cook had also ordered the flogging of three Tongan Islanders - including chiefly ones - for stealing from the ships, which led to Bligh being attacked by Tongans on one of the Resolution's hunting expeditions. Two days before the Bounty mutiny, on 26 April 1789, many Tongans had already badly molested Bligh's watering party, which was led by Fletcher Christian. To retrieve a grapnel stolen from the Bounty, Bligh had held four Tongan chiefs hostage - one of whom was the father of a man flogged by Cook - and charged them with degrading, menial tasks. After the mutiny, on 2 May 1789, when the Tongans saw that the British were reduced to a small group cramped into a solitary long boat, they gathered by the hundreds, fiercely determined to attack Bligh and his 18 loyalists. A massacre was only avoided thanks to Bligh's perspicacity, and only one sailor lost his life. ${ }^{23} \mathrm{He}$ guessed that an attack was eminent; he organised the hasty retreat of his men onto the boat and was able to sail away in the nick of time.

The Dutch discovery of the islands of Tafahi and Niuatoputapu is interesting for the study of Polynesian migration, and may further contribute to the contextualisation of the Bounty. Indeed, the lexical notes of the Dutch show that the inhabitants spoke Samoan. ${ }^{24}$ Today, however, following their 18th-century annexation by Tonga, they speak Tongan.

22 Anne Salmond, Bligh: William Bligh in the South Seas, Auckland, Penguin Viking, 2011, p 65.

23 Salmond, 2011, pp 63-65, 218.

24 Willem C Schouten, The Relation of a Wonderfull Voiage made by Willem Cornelison Schouten of Horne. Shewing how South from the Straights of Magelan in Terra Delfuego: He Found and Discovered a Newe Passage through the Great South Seaes, and That Way Sayled Round about the World, London, Nathanaell Newbery, 1619. 
This confirms that, at the time of contact with Europeans, there were still relations and exchange of information between the people of these two archipelagos.

After leaving Niuatoputapu, the Dutch landed in Futuna where, for the first time, Europeans attended a kava ceremony offered in honour of the dignitaries from the neighbouring island of 'Alofi. In contrast with the Spaniards, the Dutch were eager to document Pacific canoes and, in addition to sketching the tongiaki, they contributed a chart detailing the fleet of 50 double canoes that gathered from 'Alofi to attend the kava ceremony. These vaka foulua, which is the Futunan equivalent of tongiaki, were similar to the Tongan ones and as large as the Dutch ships in Futuna Bay.

Abel Tasman was the next Dutch navigator to explore the Pacific, sailing there from southern Australia in 1642. There he had discovered Tasmania and Aotearoa/New Zealand, approaching the latter from the south and naming it Statenland (Land of the States). Tasman was the first European to make contact with the Maori of New Zealand, the only Polynesians - along with those of Rapa Nui/Easter Island - to settle on subtropical islands where breadfruit trees did not grow. Four of Tasman's men were killed for violating taboo during an encounter with the Maori in the bay where he had anchored. He named the place Moordenaarsbaai (Murderers' Bay). The reputation of the Maori was sealed.

Not wanting to endanger the lives of his men through further encounters with the Maori, Tasman steered away from New Zealand. Heading north, he anchored at the island of Tongatabu, where the crew bartered with the Islanders and collected water in peace. Perhaps the Tongans were unaware of the tongiaki and the Niuatoputapu attacks? This is highly unlikely, because Tongatabu was home to the Tu'i Kanokupolu, a powerful dynasty that had conquered all of Tonga, including Niuatoputapu where Le Maire and Schouten were assaulted in 1616. More probable is that the sovereign was aware of the damage that European weapons could cause and chose to protect his people from such conflict. The Dutch were perplexed by his warm and friendly welcome; when Cook visited the island, 160 years later, he was given a similar reception, leading him to name the archipelago 'Friendly Islands'. 
Tasman then headed north-east. He discovered Fiji and compared the inhabitants to Hottentots, owing to their skin colour. He tacked between the many islands of the archipelago - not complaining once about his interactions with the Islanders - before reaching New Guinea.

Before discussing the voyage of the next Dutch explorer to cross the Pacific Ocean, Jacob Roggeveen in 1722, it is important to mention an unusual event that occurred in the Philippines in the meantime, and which highlights the outstanding navigation skills of the Micronesians.

In 1686, Spanish admiral Francisco Lazeano found an island east of the Philippines, which he initially named San Barnabas, but later renamed Carolina in honour of King Charles II of Spain. In 1696, some Pacific Islanders who were shipwrecked in these islands were rescued by Islanders from the Philippines and, as soon as they had learnt enough Spanish, explained that they had sailed from a group of islands to the east. They were asked by the Spaniards in the Philippines to use stone to create a rough map of the islands, which revealed that the shipwrecked Islanders were Micronesians who had travelled over 1,000 kilometres between the Carolina and the Mariana islands. This confirms that, at that time, the Micronesians and Polynesians continued to sail long distances across the Pacific.

Roggeveen sailed into the Pacific via Cape Horn with three ships, following Le Maire and Schouten's route. On Easter day, 5 April 1722, he made landfall on an unknown island. A few Islanders climbed on board his vessel and helped themselves to a small number of items. The next day, Roggeveen organised a punitive expedition, the first of a long series of European massacres on Rapanui, which was renamed Easter Island to mark this event. While Roggeveen explored the unique statues of Rapanui, the island was of no particular interest to him as it did not appear to have any gold or breadfruit. Roggeveen headed west in search of the famed southern continent, sailing through the Tuamotu archipelago - only the second European ship to enter the Dangerous archipelago after Quirós. The Africaanshe Galey, one of Roggeveen's three ships, ran aground on the island of Takapoto. The surviving sailors were rescued and dispatched to the other two ships, which departed immediately. This incident was not forgotten by the Islanders. During his onward voyage, Roggeveen noted the discovery of a few low-lying islands, probably Arutua and Apataki, and the south coast of Rangiroa. On 2 June, he sighted more elevated terrain on the Island of Makatea. Some of Roggeveen's boats rowed ashore for 
fresh food. The first encounters with the Islanders were friendly enough, as long as Roggeveen's men did not attempt to climb the cliffs on the island's shore. When they did, they were met with a hail of stones and some were injured. They retaliated with gunfire, wreaking havoc among the Islanders, and then retreated to their boats.

Why did the people of Makatea attack the Dutch seamen? Probably for the same reasons the Tahitians attacked naval officer Samuel Wallis and his Dolphin in 1767 (discussed further below): Makatea belonged to Mihiroa, a cultural area in the Tuamotu that had close cultural and language links with the Society Islands. Like the Tahitians, the inhabitants of Makatea were informed that white people had made violent contact in the Marquesas.

Fleeing Makatea, the Dutch made their way west towards the Society Islands. On 6 June, Roggeveen sighted Bora Bora and Maupiti, which he mistook for Niuatoputapu and Tafahi, recorded by Le Maire and Schouten. While Roggeveen decided against stopping at these islands, it could be argued that the European discovery of the Society Islands should be attributed to the Dutch rather than to British James Cook. ${ }^{25}$

On 13 June 1722, Roggeveen anchored in sight of another group of islands. His ships were soon surrounded by several canoes filled with Islanders whom he described as tall and robust and reminiscent of the people of Rapa Nui. Like them, their naked bodies were covered in 'paintings'. ${ }^{26}$ He noted smoke rising from several places on the shore, which suggested that the islands were densely populated. Roggeveen had landed in Samoa. For lack of safe anchorage, however, he sailed on to Batavia. By deciding against making a landfall in Samoa, he probably escaped disaster, for it must be remembered that the tongiaki intercepted by Le Maire and Schouten had been sailing from Samoa and the Samoans were bound to have heard of the tragedy. Louis-Antoine de Bougainville also decided against making a landing when he sailed across the archipelago in 1768. His compatriot, Jean-François La Perouse, being more curious, decided to visit the islands in 1787 . He paid a high price for his decision, losing his deputy Fleuriot de Langle to hostile Islanders armed with stones and clubs. Four years later, in 1791, the Pandora, with 14 Bounty prisoners

25 Andrew Sharp (ed), The Journal of Jacob Roggeveen, Oxford, Clarendon Press, 1970.

26 Marie-Charlotte Laroche, 'Circonstances et vicissitudes du voyage de découverte dans le Pacifique Sud de l'exploration Roggeveen 1721-1722', Journal de la Société des Océanistes, vol 38, no 74-75, 1982, pp 19-23. 
on board, and her tender the Matavy - originally named the Resolution by James Morrison, the Bounty's boatswain's mate who had built her in Tahiti - also approached the Samoan archipelago. The Islanders on the small atoll of Nukunonu fled the area overnight to avoid them, whereas, on the larger Tutuila, the crew was attacked by a strong fleet of canoes. At Tutuila, incidentally, the Pandora sailors found the uniform of one of La Perouse's murdered men.

These case studies demonstrate that the nature of the encounters between Europeans and Islanders varied between archipelagos, and depended on factors such as how warlike the Islanders were at the moment of contact, their social organisation and religious beliefs, and their population. The inhabitants of high islands, which were generally more populated than atolls, could afford to be more belligerent. The nature of the encounter also depended on the objectives and behaviours of the Europeans: what they had come for and how long they spent on islands. Many 16th- to 18th-century European explorers had strong characters and left a deep and lasting impact on the Pacific Islands that they visited. What may be said about the Spanish and Dutch navigators is that they showed little curiosity about the life, culture and history of the indigenous peoples. While they noticed Pacific Islanders travelling across the ocean at the same time as them - and in spite of the shipbuilding and navigational difficulties they experienced, especially in the 16th century - they did not consider how the remote islands of the Pacific had been settled as early as the Stone Age. There is no way of knowing, for instance, whether the canoes observed by the Spanish in Tahuata were the same as those drawn by Cook on the same spot a century and a half later. Had there been any developments in native shipbuilding? It cannot be ascertained.

The Polynesians kept a close record of all European incursions. Since the first fatal contact in Tahuata, they had been wary of European ships approaching their shores. If any ventured near, they either did their utmost to repel them, or were deliberately submissive to avoid reprisals, knowing that the cannons of the outsiders made them invincible. They showed no mercy, however, in the face of European weakness. This scenario was repeated on each South Pacific island approached by European ships. The navigators who followed the Spanish and the Dutch, including the Bounty, paid the price for the actions of their predecessors. 


\section{The era of scientific expeditions}

\section{The English rediscover breadfruit}

The Marquesans cannot but have been unsettled by the tragic episode of the Spanish landfall in Tahuata, which was reported from island to island. The story crossed the South Pacific Ocean and, after travelling through the Tuamotus, eventually reached the Society Islands, 1,500 kilometres away. In 1769, 174 years after the event, Tupaia recounted the story to James Cook. It is no surprise that, being the first Europeans to land in Tahiti in 1767, Samuel Wallis and his crew were not made to feel welcome. Ari'i Amo, the king ${ }^{27}$ of Tahiti, and Queen Purea, his wife, immediately recognised them as the infamous whites described by the Marquesans. The Tahitian army was summoned and their fleet of 100 pahi tama'i (double war canoes) was gathered. The canoes were loaded with stones before launching an assault on the Dolphin. The attack continued for four days without respite, until the Dolphin's cannons shattered the Tahitian fleet and army. Gunshots were fired into the crowd on shore and several houses were destroyed, which caused the Islanders to panic. The Marquesans had been right: these white men were invincible. Ari' $i$ Amo resolved to surrender. He sent the queen to negotiate with Wallis, and the Tahitians adopted a friendlier approach towards the visitors. In the aftermath, Wallis could not understand why such a welcoming people had initially waged such fierce battle against them. He found them so affable that he later downplayed the battle, reporting no more than four Tahitian casualties. The truth was later revealed by the Dolphin's quartermaster, George Robertson, who provided a full account of the scale of the attacks and of the violence of the British response. ${ }^{28}$

Wallis' Dolphin and Philip Carteret's Swallow departed together from England in search of Terra Australis, but their ships were separated once they sailed into the Pacific. Wallis continued his journey alone and discovered Tahiti, while Carteret sailed on in a southerly direction. On 2 July 1767, Robert Pitcairn, a 15-year-old sailor, sighted an island and it was named after him. Battered by violent breakers, landfall could not be made. The Bounty mutineers' ultimate island was then uninhabited, yet

\footnotetext{
27 The terms 'queen' and 'king' were given to the ari ' $i$ by European explorers.

28 George Robertson, An Account of the Discovery of Tahiti. From the Journal of George Robertson, Master of HMS Dolphin, London, Folio Society, 1955.
} 
Polynesians had lived there, and on neighbouring Henderson, between the 10th and the 16th centuries. They had introduced the 'uru and several other varieties of trees and had built marae (temples). ${ }^{29}$ Pitcairn lay on the Polynesian route from Mangareva to Rapa Nui. Tahitian legends about the mythical navigator Rata recall frequent interaction between the Gambier Islands, Pitcairn and the three other islands in the area: Oeno, Ducie and Henderson. All of them were mapped by Tupaia. Mangarevan narratives also testify to heroes calling at these islands when travelling to and from Rapa Nui. Further information concerning the Polynesian settlement of Pitcairn is provided in Chapter 2.

Louis-Antoine de Bougainville landed in Tahiti the year after Wallis, in 1768. Little did he know that his rival British explorer was to thank for the warm welcome he received. He dubbed Tahitians the kindest people on earth, and the Island of Tahiti, 'Paradise regained' or 'New Cythera.'.

Given this reputation, it was only natural that the British Admiralty should choose Tahiti as home for a scientific expedition led by Lieutenant James Cook, with an official purpose to observe the transit of Venus in 1769. Two centuries after the Spanish, Joseph Banks, Daniel Carlsson Solander and Sydney Parkinson, all renowned European naturalists, were thus allowed to take a fresh interest in breadfruit, of which they provided detailed descriptions and several sketches. Echoing Quirós, their praise resuscitated interest in the fruit. Like Marquesans, Tahitians were keen on breadfruit, which they called 'uru (not mei as in the Marquesas). As their staple food, its flowering and fruiting determined Tahitian seasons: tau 'aubune was the season of plenty, when 'uru was abundant; and tau o' $e$ the season of scarcity. The shift from tau o' $e$ to tau 'auhune was marked by the rise of a cluster of small stars, Matari ' $i$ (the Pleiades or 'Small Eyes'). Matari' $i$ sparkle at twilight above the horizon around 20 November, when breadfruit trees are in bloom. It was the occasion for Tahitians to celebrate returning abundance: they would serve huge collective meals with breadfruit galore; sing päta' uta' $u$ songs in celebration of the ' $u r u$; and attend performances by 'arioi (professional performers and followers of 'Oro, the god of fertility and abundance). Everyone was invited, including deities and the deceased.

29 Kirch, 1988, pp 26-31.

30 Louis-Antoine de Bougainville, Voyage autour du Monde par la Frégate du Roi La Boudeuse et la Flûte l'Etoile (1767-68), Paris, La Découverte Poche, 1997 (1771), p 131. 
The period of abundance lasted for six months, until late May, when festivities came to an end. Deities and the deceased were urged to return to the spirit world. Breadfruit season was over. Tahitians now had to tap into the fermentation pits where breadfruit was stored. The Pleiades were thus a Tahitian time marker. Their appearance and disappearance at dusk allowed Tahitians to attune their lunar calendar to their astral calendar and to the cycle of seasons.

Cook and his crew stayed in Tahiti at the time of plenty. They noticed that special care was bestowed on breadfruit trees, which provided for the Tahitians' needs. As the Spaniards also observed in the Marquesas, only part of the harvest was consumed during the season of plenty and the surplus was spared for the fermentation pits, in anticipation of the forthcoming season of scarcity. Some time after they had sailed back to England, and at the recommendation of Banks, the British Admiralty decided to harvest and transplant breadfruit saplings to the West Indies to provide cheap food for the slaves of the colonies. The breadfruit mission was entrusted to Lieutenant William Bligh on the Bounty in 1788. The English, therefore, embarked on the same mission that Quirós had envisioned and suggested to the king of Spain, to no avail, two centuries earlier.

\section{The origins of the breadfruit tree}

The mei or 'uru (Artocarpus altilis) tree is of the Moraceae family and originates from South-East Asia. ${ }^{31}$ Different species of Artocarpus grow naturally in Indonesian forests, and all belong to the jackfruit genus (Artocarpus heterophyllus). It is from this species that the three tree varieties found in Oceania derive. The first variety, Artocarpus camansi, is native to New Guinea and has spread over to the Philippines. It is closely related to Artocarpus altilis, the Polynesian breadfruit tree. Like the latter, its fruit is harvested as a staple food, but it is mainly the seeds, rather than the flesh, that are eaten. Artocarpus mariannensis, the second variety, is only grown in Micronesia, also mostly for its seeds. Artocarpus altilis, the third variety, is the only species that made it to Polynesia. It is a seedless species and consumed for its flesh. Originally from New Guinea, it was domesticated in Melanesia. Figure 1.1 plots the original distribution areas of the three species of breadfruit.

31 Arthur W Whistler, Plants of the Canoe People, Lawai, Kauai, Hawai i, National Tropical Botanical Garden, 2009. 


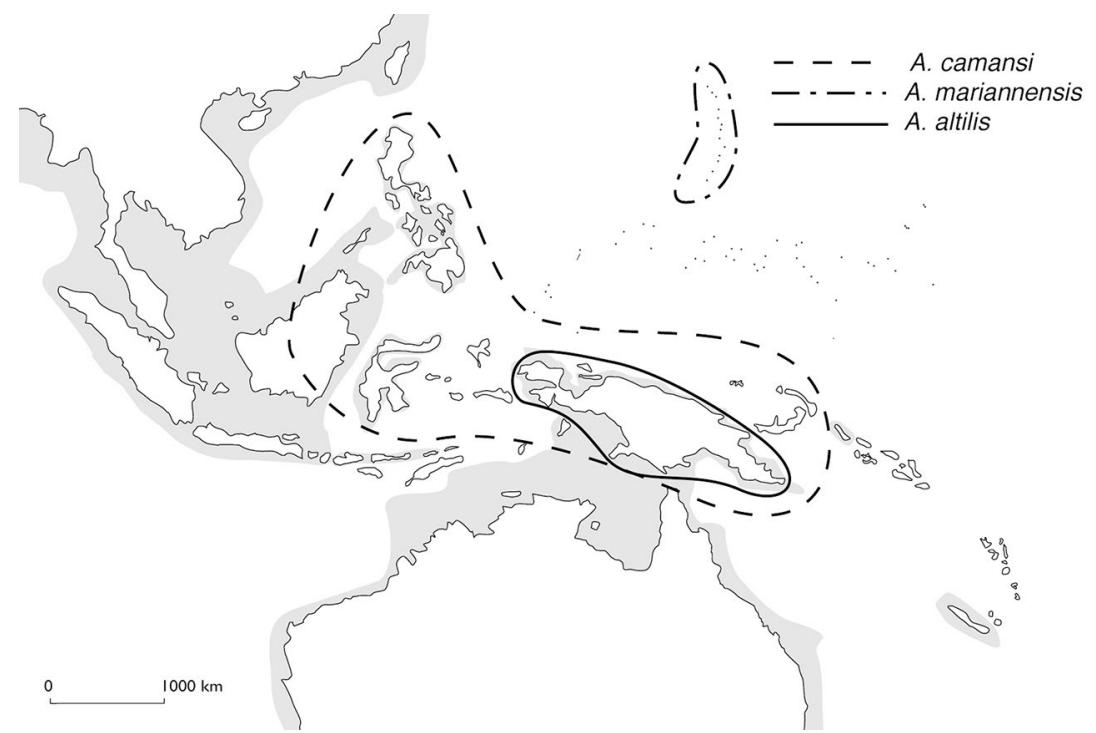

Figure 1.1. Geographic origin of the breadfruit and related species. The shaded areas correspond to the lands that emerged during the last glaciation about 10,000 years ago.

Source: Lebot (2002, pp 114-15).

One needs to distinguish three distribution areas: the area of origin, where the species can be found in the wild; the domestication area, where it was first purposefully replanted; and the diversification area, where careful cultivation has generated several cultivars. ${ }^{32}$ Concerning Artocarpus altilis, Melanesia is both its origin and domestication area, and Polynesia is its diversification area. ${ }^{33}$ Wild species seem to grow only in New Guinea, whereas only cultivated forms can be found elsewhere in Melanesia. ${ }^{34}$ Human agency introduced Artocarpus altilis into eastern Polynesia, the Marquesas, Hawai $\mathrm{i}$ and other tiny atolls. Without doubt, it has also been repeatedly modified by humans, by means of seeds and suckers, ${ }^{35}$ self-fertilisation and cross-fertilisation, as part of a slow, complex and ever-evolving process of domestication and diversification. Because it is a

32 A cultivar is a plant variety that has been obtained through growing, generally after selection for its arguably unique characteristics. The selection process might be for aesthetic or technical purposes, or depend on growth speed, resistance to diseases or adaptation to biotopes.

33 Annie Walter, 'Notes sur les cultivars d'arbre à pain dans le Nord de Vanuatu', Journal de la Société des Océanistes, vol 88, no 1, 1989, pp 3-18.

34 Vincent Lebot, 'La domestication des plantes en Océanie et les contraintes de la voie asexuée', Journal de la Société des Océanistes, 2002, pp 114-15.

35 A sucker is a shoot that springs from the root of a vegetable. It may grow autonomously and be replanted as a new individual. This offspring is genetically identical to its mother plant. 
seedless species, it can be extensively cultivated by transplanting suckers. Breadfruit trees found in forests are residues of former plantations. They do not grow in regions outside the tropics, such as Rapa Nui or New Zealand.

It is highly likely that the Lapita populations that spread from northern Melanesia to western Polynesia around 3,000 years ago also spread the breadfruit plant. Linguists have been able to reconstruct a Proto-MalayoPolynesian (PMP) etymon of Artocarpus: *kuluR, which designates the species that grows naturally in Indonesian forests. As they journeyed to the central Pacific, settlers transplanted the plant and, through selection, created a new species, Artocarpus altilis, which has retained ${ }^{*} k u l u R$, its original Malayo-Polynesian designation, in Proto-Oceanic (POC) language. It is from this etymon that reflections in Polynesian languages are derived. ${ }^{36} \mathrm{~A}$ comparison of cognates of " $u l u$ ' in Polynesian languages shows that "uru', or its cognates in other Polynesian languages, is the generic term for breadfruit in one area of Polynesia. In another area ' $m e i$ ' prevails, as in the Marquesas Islands. In Tahiti, the two terms coexist as "uru' and 'may-ore'. The noun "uru' is derived from the PMP * $k u l u R$, while 'mei' is derived directly from the Proto-Austronesian (PAN) ${ }^{*} K m a(\eta)(s) i$, which is known as ${ }^{*} M a R o$ in Proto-Remote-Oceanian (PROC). Moreover, ' $m e$ ' prevails in all Micronesian languages. ${ }^{37}$ The wide distribution of ' $m e i$ ' and "uru' across Oceania makes it hard to determine which is the etymon. It may be presumed that one was the generic name in the first place, and that the other designates a variety that gradually supplanted it and thus became a generic term, too. Linguists have not yet resolved this issue.

\section{The cultural uses of breadfruit}

Breadfruit trees are mainly used for their food: their edible fruit was formerly the staple food of tropical eastern Polynesia. Polynesians generally steam breadfruit, either in traditional ovens (umu) once they have been peeled, or simply on a wood fire with their skin intact: the skin protects the flesh and, once fully charred, is scraped off before the flesh is consumed. The flesh may also be kneaded and mixed with coconut milk, which makes a kind of sweet dough called $k a$ 'aku in the Marquesas. In anticipation of the season of scarcity, peeled breadfruit is stored for several months in underground silos lined with cordyline sheets

36 SJ Greenhill \& R Clark, 'POLLEX-Online: The Polynesian Lexicon Project Online', Oceanic Linguistics, vol 50, no 2, 2011, pp 551-59, pollex.org.nz.

37 Micronesian Comparative Dictionary, www.trussel2.com/mcd/pmc-intro.htm. 
for insulation from the soil. This fermented sour dough is called māhi in Tahiti and $m \bar{a}$ in the Marquesas. It may be consumed raw during the season of scarcity or on sea voyages. Polynesians, however, seem to prefer it kneaded and mixed with newly plucked and freshly steamed fruit. This dough, called poppoi or $p o i$, tastes less bitter and is generally served as a side dish. Cooking methods may vary according to cultivars. For instance, some varieties cannot be cooked on a wood fire, while others have a softer flesh that mixes easily with coconut milk.

In traditional medicine, sap, buds, young shoots, fruit stalks, petioles, mouldy pulp and even the inner bark of young branches were used for various cures. Flowers, for example, were toasted and rubbed on gums to relieve toothache. The white latex sap that flows from the bark was used as chewing gum or cosmetics. Men applied it fresh to flatten their hair back. Women boiled the sap with monoi in a clamshell (pahua) above a flame before applying it to their hair, too. It was also used to make poultices on sprains, muscle strains and contusions, and to catch birds. Eventually, the bark of young branches came to be used for the production of beigetinted tapa (bark cloth).

Where breadfruit trees proved most valuable was in shipbuilding. In Tahitian forests, one can feel very small in the presence of majestic breadfruit tree trunks that tower 25 metres high, with their fruit completely out of reach. Their timber was once coveted for large canoe building. Polynesians would carve planks of 2-10 metres in length and 0.5-1 metres in width; these were sewn together with sinnet and calibrated and adjusted to make the hulls of canoes. Latex was mixed with coconut fibre and served as pitch to caulk seam holes, seams and cracks. After the Bounty mutiny, such Tahitian building techniques were put to good use by James Morrison in the collective building of the Resolution, a schooner with which he intended to sail from Tahiti to Batavia before working his way on to England. Shortly after construction, however, the Resolution was seized by the British authorities of the Pandora and renamed Matavy. Under British stewardship, the Matavy made a valiant voyage as far as Batavia, where she was sold off to carry on plying the Indian Ocean until a venerable old age. She thus fared much better than the Pandora, which ran aground on the Great Barrier Reef with her Bounty prisoners on board.

Tahitians were able to build canoes measuring well over 20 metres in length, with the longest recorded by James Cook extending 33 metres. During his second voyage in 1774, Cook recorded a fleet of over 
300 canoes in Tahiti, including 160 double canoes. Since this single fleet covered only part of Tahiti and did not include small fishing canoes, the total Tahitian fleet at the time may have numbered in the thousands. The building of those canoes claimed much breadfruit timber. It was therefore necessary to plant tens of thousands of trees to sustain shipbuilding, and the same amount again for food. Under such circumstances, the fact that Tahitians agreed to cede many saplings to help William Bligh fulfil both of his breadfruit missions, first on the Bounty and then again on the Providence, testifies to one of the principal arguments of this paper. In the absence of alternative methods, Polynesian Islanders were willing to comply with the whims of Europeans rather than confront their wrath.

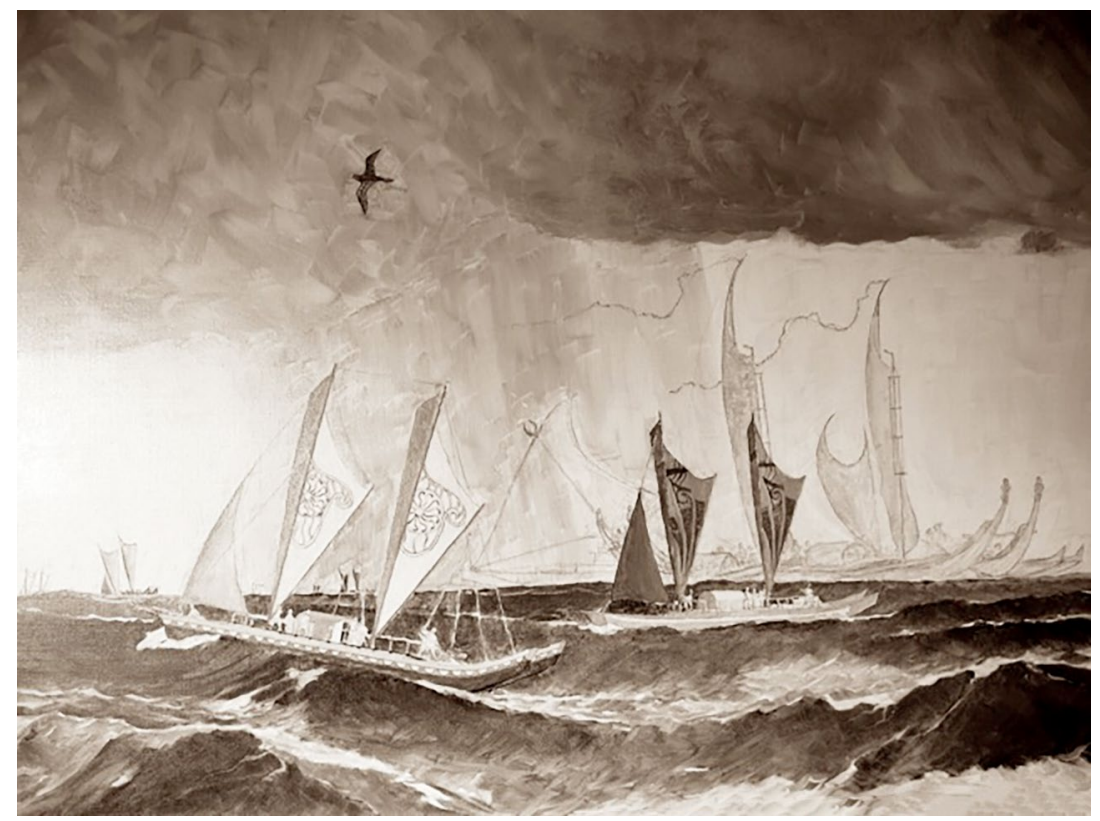

Figure 1.2. In this painting, modern double canoes built on the model of the old double canoes, are visible in the foreground while, in the background, like ghosts of the past, the silhouette of the old double canoes is evident.

Source: Henri Python (n.d.). 


\section{English discovery of Polynesian maritime science}

\section{Tupaia tells the English about Mendaña's call at the Marquesas}

It was only after James Cook's first visit to Tahiti that the dramatic shifts in Tahitian behaviour towards Samuel Wallis started making sense. The clues were supplied by Tupaia, who narrated the Spanish attack in Tahuata in 1595. Tupaia specifically marked this tragic event on the map that he drew at Cook's request. The map featured all of the lands known to Tupaia, from the Marquesas to Fiji.

Tupaia's map recorded four narratives about European vessels calling at Pacific Islands, including at Tahuata. ${ }^{38}$ According to Tupaia, historically four islands were visited by ships similar to those of the English. One of the islands on Tupaia's map that is of particular interest to this essay was spelled 'Ohevatoutouai'. Experts now agree that it corresponds to Tahuata in the Marquesas. ${ }^{39}$ The accompanying comment states that a European ship had called there long before. Tupaia did not provide a date, but the Tahitian measure of time was generations, which they called $u^{\prime} i$. For instance, any event that had occurred at the time of one's parents was said to be two $u^{\prime} i$ (two generations old - one's own and one's parents). If the event occurred during the time of grandparents it was three $u^{i} i$ old. If from the time of great-grandparents, it was four $u^{\prime} i$ old. Tahitians stopped counting beyond four $u^{\prime} i$. Events in the deeper past became incorporated into genealogical narratives. Since Tupaia did not date the Tahuata events according to $u^{i} i$ counts, it can be inferred that they occurred in the distant past. His recitation of his genealogy made no sense to the foreigners, who had insufficient knowledge of Tahitian language and culture. The British could not fathom that the seven or eight named ancestors were time markers, and they paid them scant attention.

38 Robert Koenig, 'Les navires européens de la carte de Tupaia. Une tentative d'identification', Bulletin de la Société des études océaniennes, no 217, 1981, pp 985-91.

39 HAH Driessen, 'Outriggerless Canoes and Glorious Beings: Pre-Contact Prophecies in the Society Islands', Journal of Pacific History, vol 17, no 1, 1982, pp 3-28. 
In reference to the European call at Tahuata, Tupaia stated: 'maa te taata, pahi rahi, iti te pahi no Britane'. A form of Tahitian pidgin, the sentence literally translates as either 'food men, ship(s) large, small ship of the British', or 'many men, ship(s) large, small ship of the British'. This in turn may mean 'some men took food, their ships were larger than those of the British', or 'some men were eaten, their ships were larger than those of the British' or, alternatively, 'there was a crowd (on board), their ships were larger than those of the British'. Since no European ships had sailed into this archipelago since Mendaña, Tupaia must have been referring to the four Spanish vessels that had anchored there to restock. Arriving in 1774, Cook was thus only the second European explorer to visit the archipelago, and Tupaia was telling him the narrative of Mendaña's call at the Marquesas. It may be inferred that, when the Tahitians saw Wallis' ship, they assumed the Spaniards had returned and therefore launched an attack.

Tupaia's map contained other valuable information, including one of prime interest to Bounty history. While Tahiti stood in the centre of the map, a group of islands with names prefixed by Hiti figured on the edges. According to Teuira Henry, ${ }^{40}$ the three outermost of these islands, named Hiti-tautaumai, Hiti-tautaureva and Hiti-tautauatu, correspond to Oeno, Henderson and Ducie, east of the Gambier Islands. Henry also claims that Pitcairn Island was called Hiti-aurereva. These islands were quoted in Henry's Rata legend ${ }^{41}$ (see Molle \& Hermann, Chapter 2).

\section{Polynesians were apprised of each passing European vessel}

Tupaia also noted that another European ship had sailed past Ra'iatea. The statement on the map referring to Ra'iatea said: 'Tupuna nō Tuapaia, pahi taio', which literally translates as 'Tupaia grandparents, ship(s) friend(s)'. In other words: 'in the time of Tupaia's grandparents, there was/were (some) friendly vessel(s)'. Tupaia was not yet born when Jacob Roggeveen sailed past Bora Bora and Maupiti in 1722. The English believed that he was in his $40 \mathrm{~s}$ in 1769 , which places his birthdate between 1724 and 1729 , and therefore it was not possible for him to have seen the

40 Teuira Henry, Tahiti aux Temps Anciens, Société des océanistes, no 1, Paris, Musée de l'Homme, 1968, pp 75-76.

41 Henry, 1968, pp 488-500. 
ships in 1722 . His grandparents, however, may have spotted them on the horizon. As the ships did not stop, they caused no harm and were categorised as 'friendly' ships.

Tupaia also made reference to a European shipwreck near 'Anaa in the Tuamotu Islands: 'Tupaia, ta' ata nō pahi mate'. This translates as 'Tupaia, people of the ship dead', and may be interpreted as 'in Tupaia's time, the passengers of a ship perished'. Could it have been the Africaanshe Galey, one of Roggeveen's three ships that ran aground on Takapoto's reef in 1722 ? If this was the case, it may seem that Tupaia was mistaken about the date as the shipwreck occurred during his grandfather's time. It must be noted, however, that a couple of years may have elapsed before news of the shipwreck reached Tahiti. A couple of years after the event, in 1724, Tupaia may have been born, in which case the event may indeed coincide with 'Tupaia's time'. What Tupaia did not know was that the ship that was lost in the Tuamotus was part of the same fleet sighted off Ra'iatea and sailed in the same year.

Why did Tupaia locate the shipwreck on 'Anaa and not Takapoto? Once again, Tupaia was not misinformed. At the time, most of the westerly Tuamotu Islands were virtually under the control of the 'Anaa warriors, ${ }^{42}$ and Tahitians had no other name for the Tuamotu archipelago than Fenua 'Anaa, the 'Land of the people of 'Anaa'.

Tupaia declared that Samuel Wallis was not the first European to have discovered Tahiti; another ship had called there before him. Given that no European nation or explorer claimed to have discovered Tahiti before Wallis, it is impossible to determine to whom Tupaia was referring. According to Tupaia, it was an 'enemy' ship that clashed with the Islanders: 'Metua o te o tupuna Tupaia pahi toa', which translates as 'at the time of Tupaia's grandparents' ancestors, an enemy ship (appeared)'. Some scholars have speculated that Tupaia was referring to the San Lesme, one of Juan Sebastián Elcano's Spanish ships that, according to Robert Langdon, ran aground on the Amanu reef in the Tuamotu. ${ }^{43}$ Two ship's guns were excavated from the reef in 1969, which confirmed a shipwreck. Langdon suggests that the ship may have sailed past Tahiti before sinking in Amanu in 1526, 243 years (12 generations) before Tupaia's time. For Tupaia,

42 Frédéric Torrente, Buveurs de Mers Mangeurs de Terres, Papeete, Te Pito O Te Fenua, 2012.

43 Langdon, 1978. 
this went back to ancient times. Langdon's hypothesis is now strongly disputed because recent studies have identified the guns as being of more recent manufacture. ${ }^{44}$

Be that as it may, Tupaia's map is evidence that the European ships that sailed the South Pacific were sighted, recorded and reported to the inhabitants of other islands. Polynesians knew what they had to do as soon as they spotted a European ship on the horizon. This state of affairs even allowed some tabu'a to make prophecies. One of them, Vaita, high priest of Taputapuatea, prophesied shortly before Wallis' arrival that canoes without outriggers would be coming. When he was met with disbelief, he set a 'umete (flat, oblong wooden dish) afloat with stones in the bottom. The craft did not capsize, contrary to the general opinion of the time. ${ }^{45}$

In eastern Polynesia, the last great clash between Europeans and Polynesians occurred in Tubua $i$, 500 kilometres south of Tahiti, in the Austral Islands. Tupaia reported the existence of Tubua i to James Cook in 1769 while they were off the coast of its neighbouring island Rurutu. In his quest to discover the famed southern continent, Cook took an interest in information about all the lands in the vicinity. Tupaia also informed him of Mutu, an island within a day's sailing to the east, which he recorded on his map. It was not until Cook's third voyage in 1777 that he sailed to this island, known to its inhabitants as Tupua'i (Tubua ii). The approaching Resolution was hemmed in by many canoes and Cook noticed with surprise that the Islanders spoke Tahitian, and were therefore closely related to the people of the Society Islands. One of their chiefs even bore the Tamatoa title, which was held by the most prestigious Society Island ari' $i$, Opo'a, in Ra'iatea. Ra'iatea is home to the Taputapuatea marae, the international marae of which none other than Tupaia was high priest. The people of Tubua'i had likely been informed by those of the Society Islands about European visitors. They knew they were a threat and would probably attempt an attack. Cook, however, deeming the pass too hazardous to navigate, decided against laying anchor in the lagoon and sailed away. It may be surmised that he very narrowly escaped an ambush.

44 Max Guerout, 'Les vestiges d'Amanu', Bulletin de la Société des Etudes Océaniennes, no 292/293, 2002, pp 12-23.

45 Henry, 1968, pp 4-5. 
The Bounty was not so fortunate when it ventured into the lagoon 20 years later. Carrying Fletcher Christian and his mutineers in search of a safe settlement, Tubua'i was Christian's preferred choice. As might be expected, however, the mutineers were not welcome and were ambushed by the Tubua' $i$ warriors who allowed the ship to sail into the lagoon before launching an attack with their war canoes loaded with stones. The mutineers returned fire. The bloodshed was such that the location of the battle is known as Bloody Bay.

The Bounty headed back to Tahiti to briefly restock and returned to Tubua' $i$ on 23 June 1789. Tamatoa gave them a courteous welcome on this occasion, most likely to avoid a repeat of the earlier carnage. Tensions remained high, however, and during one particularly bloody battle, 66 indigenous people lost their lives. Christian eventually had to concede that Tubua $i$ was not the place for them to settle and the mutineers departed in search for a safer location.

\section{European recognition of Polynesians as navigators}

It wasn't until James Cook's voyages that the navigation skills of Polynesians became known to Europeans. The turning point was when Tupaia sailed with Cook and, aside from creating his famed map, he imparted a deep knowledge of Tahitian maritime science. It came to be understood that Tahitians had considerable navigational experience and were acquainted with many islands. Joseph Banks noted in his journal on 12 July 1769, on the eve of their departure from Tahiti:

This morn Tupia came on board, he had renewed his resolves of going with us to England, a circumstance which gives me much satisfaction. He is certainly a most proper man, well born, chief Tahowa or priest of this Island, consequently skilled in the mysteries of their religion; but what makes him more than anything else desireable is his experience in the navigation of these people and knowledge of the Islands in these seas; he has told us the names of above 70 , the most of which he has himself been at. ${ }^{46}$

46 Joseph Banks, Banks's Journal: Daily Entries, 12 July 1769, southseas.nla.gov.au/journals/banks/ about.html 
According to Banks, Tupaia was a tahu' $a,{ }^{47}$ a 'priest' in conjunction with a navigator. His knowledge proved invaluable, both to the continuation of Cook's voyage, and to contemporary understanding of the scientific achievements of 18th-century Polynesians.

Five years after Tupaia's voyage, young Puhoro - another Tahitian navigator who steered the Spanish across the Pacific - was taken to Peru by Captain Jose de Andia y Varela in 1774 and impressed people with his expertise in reading the winds. He divided the horizon into 16 sectors, each bearing a name and showing a different direction, as on a compass board. Andia y Varela noted:

One of them named Puhoro came to Lima on this occasion in the frigate, and from him and others, I was able to find out the method by which they navigate on the high seas: which is the following. They have no mariner's compass, but divide the horizon into sixteen parts, taking for the cardinal points those at which the sun rises and sets ... He knows the direction in which his destination bears: he sees, also, whether he has the wind aft, or on one or other beam, or on the quarter. ${ }^{48}$

Puhoro explained that, to navigate at night, Polynesians read the stars, of which they knew a vast number:

When the night is a clear one, they steer by the stars; and this is the easiest navigation for them because, these being many [in number], not only do they note by them the bearing on which the several islands with which they are in touch lie, but also the harbours in them, so that they make straight for the entrance by following the rhumb of the particular star that rises or sets over it; and they hit it off with as much precision as the most expert navigator of civilized nations could achieve. ${ }^{49}$

As reported by Andia y Varela, the art of navigating was the preserve of Polynesian master mariners called $f a$ atere: 'There are many master mariners among the people, the term for whom is in their language fatere'..$^{50}$ The

47 Tahu'a: an expert, one who has special knowledge; for instance, a tahu'a va' $a$ is expert in canoebuilding; a tahu'a fare is expert in house-building; a tahu'a tautai is expert in fishing seasons; a tabu'a $r \bar{a}^{-} a u$ is a 'doctor', or expert in medicinal plants; a tahu'a pure is expert in prayers and incantations at religious ceremonies; a tahu'a marae oversees the building of marae, or religious precincts; a tahu'a-nui or tahu'a-rahi is a high priest in charge of religious ceremonies.

48 BG Corney, The Quest and Occupation of Tahiti by Emissaries of Spain during the Years 1772-6, vol 2, London, Hakluyt Society, 1913-19, p 284.

49 Corney, 1913-19, p 284.

50 Corney, 1913-19, p 284. 
term fa atere recurs in narratives about the birth of stars. ${ }^{51}$ It refers to a star or planet that steered a constellation, which itself symbolised a canoe. $F^{\prime}$ 'atere were experts in this highly developed Tahitian science. One wonders, today, what might have been the full nature of that science.

Language barriers prevented Andia y Varela, Cook, Banks and their fellow travellers from collecting more than fragments of information about traditional Polynesian navigation. To understand how Tahitians used the stars and to make sense of what Tupaia or Puhoro tried to explain to them would have required a mastery of the language. Naturalist Johann Reinhold Forster lamented this fact in his journal in 1774, during Cook's second voyage:

There is among them in each district one or more Tàtā-orrèro who knows their Cosmogony and Theogony (which I could not learn, in so short a time,) who knows their Geography, History, Winds, Stars etc., Almanac. $^{52}$

Tahitian stellar science was, therefore, not collected and studied by late 18th-century European explorers, and was all but lost by the early 19th century. It was not until 1941 that the American astronomer Maud Makemson ${ }^{53}$ resurrected the practice through her study of the 'birth of stars', as reported in Ancient Tabiti (1928). Only then did the scientific community become aware of the existence of an elaborate science of Polynesian astronomy.

Over his three Pacific voyages, Cook commented on the detail and diversity of Tahitian canoes. Artists commemorated them, too, and depicted the various models such as the pühoe, a small outrigger canoe carved in a single tree trunk; the pahi, a double sea canoe made of planks sewn together; the va'a taurua or tippaerua, a double canoe with vertical bows for coastal navigation; the pahi tama' $i$, a double war canoe operated by a hundred warriors; the va a motu, a lagoon outrigger; and the va' a tira, a double-hulled canoe with long fishing rods at its bow. ${ }^{54}$

51 Henry, 1968, pp 368-73.

52 Johann Reinhold Forster, Observations Made during a Voyage Round the World, Honolulu, University of Hawai' i, 1996 (1778), p 530.

53 Maud Makemson, The Morning Star Rises, An Account of Polynesian Astronomy, New Haven, Yale University Press, 1941.

54 J Neyret, Les Pirogues Océaniennes, Association des amis des musées de la Marine, Paris, 1974; A Haddon \& J Hornell, Canoes of Oceania, Honolulu, Bishop Museum Press, 1975; E Dodd, Polynesian Seafaring, Lymington, Hampshire, Nautical Publishing Company, 1972. 
When a large naval manoeuvre was organised by $A r{ }^{\prime} i$ Tù in Matavai Bay in 1774, Cook marvelled at the sight of more than 300 canoes with 7,000 warriors on board, ready to engage in battle with the neighbouring island of Eimeo (Mo'orea). He was told that such canoes sometimes sailed several days to distant islands and ferried back pearls, mother-of-pearl and red feathers. As a navigator, Cook appreciated that the Tahitians were master mariners who, without any instruments, steered by the stars. He noted as much in his journal:

In their longer voyages, they steer by the sun in the day, and in the night by the stars; all of which they distinguish by names, and know in what part of the heavens they will appear in any of the months during that they are visible in their horizon; they also know the time of their annual appearing and disappearing with more precision than will easily be believed by an European astronomer. ${ }^{55}$

In 1769, Cook and a group of British scientists were commissioned to observe the transit of Venus in front of the sun. Cook elected to land in Matavai Bay, at the same spot visited by Samuel Wallis in 1767. Matavai was a regular destination for British navigators during the 18th century: William Bligh on the Bounty in 1788, on which Fletcher Christian briefly returned twice in 1789; Bligh again with the Providence in 1792; and London Missionary Society (LMS) missionaries on the Duff in 1797. French and Spanish navigators also had favourite landing bays.

Cook's party built an observatory at Tefauroa - which they renamed Point Venus (now known as Pointe Vénus). The site was connected to Polynesian lore and symbolic to Tahitians. Notably, it housed Te ana-vaha-rau ('The cave-with-many-holes'), ${ }^{56}$ an initiation school for the transmission of consecrated Polynesian knowledge of cosmogony, theogony, genealogies, myths, music, history, oratory, geography, astronomy, medicine, the measurement of time, climatology, shipbuilding and navigation skills.

Most notably, Tefauroa was once home to Hiro, an outstanding legendary Polynesian navigator. Hiro's great deeds were orally transmitted and celebrated throughout eastern Polynesia and his visits are recalled to this day. In Taha'a, for example, a group of rocks bear the name Te-'üri-a-Hiro

55 John Hawkesworth, An Account of the Voyages Undertaken by Order of Her Present Majesty for Making Discoveries in the Southern Hemisphere and Successively Performed by Commodore Byron, Captain Wallis, Captain Carteret and Captain Cook, in the Dolphin ..., Drawn up from the Journals ..., London, W Stratham, 1773, p 227.

56 Translation, Henry, 1968, p 81. 
('Hiro's dog'). A large oblong stone in Maupiti is known as Te-pahi-o-Hiro ('Hiro's canoe') and a cliff, Te-tūturira' $a$-a-Hiro ('Hiro's one-knee support'). In Bora Bora, one may visit Te-timora'a-a-Hiro ('Hiro's timo game') and Te-oE-a-Hiro ('Hiro's bell'). At Huahine, Te-a-hoe-Hiro ('Hiro's paddle') can be observed in relief on a cliff. Also in Huahine, as in the Papeno'o valley in Tahiti, peaks carry the name Te-ure-a-Hiro ('Hiro's phallus'). In Ha'apape (Mahina) and Tahiti, there is a sand dune built with his own hand, Te-Mou'a-a-Hiro ('Hiro's mountain'), and a reef, To'a-Hiro ('Hiro's reef'). One of the summits on Ra ivavae Island is dedicated to him, Te-Mou'a-o-Hiro ('Hiro's mountain'). In Rapanui, where Hiro is the god of rain, there is a stone containing a natural hole that the natives call Pu o Hiro ('Hiro's horn').

As with all canoe names, the choice of name for Hiro's canoe, Höhöio ('Intriguing'), was deliberate. The day it was launched, the star 'Ana-mua (Antares) sent a gust of wind as a sign of welcome, which meant that the canoe fell under the protection of the gods. Thus imbued with mana (supernatural power transmitted by gods), the canoe participated in Hiro's legendary feats, such as towing islands while the Islanders slept (Hiro was forced to flee when the Islanders were alerted by a cock's crow). With Venus as his guide, Hiro sailed around archipelagos, sometimes meeting other heroes like Pai, the Tahitian equivalent of Hercules.

Ironically, Tefauroa has since become the seat of a number of European legends, ${ }^{57}$ the most prominent in the early contact period being that Pointe Vénus was Paradise regained. After the Bounty mutiny, Bligh himself described the place as 'the Paradise of the World' on account of his men seizing the ship allegedly to the cheers of 'Huzza for Otaheite!'58 Nowadays, Pointe Vénus is strongly associated with the near-legendary figure in British maritime culture of Cook. Through a process of enduring eulogising and mythmaking, Cook's severe mistreatment of Pacific Islanders during the course of his last voyage has all but been forgotten. At the time of the Bounty's first stay in 1788, even Tahitian chief Tu and his retinue held John Webber's portrait of Captain Cook as 'intensely sacred' and, 'taking no chances' as Anne Salmond puts it, they invoked Cook's mana alongside their Tahitian ancestors in order to summon the

57 My thanks to Sylvie Largeaud-Ortega for providing the following analytical development of Pointe Vénus's early contact and post-contact history.

58 Bligh, in Owen Rutter (ed), The Log of the Bounty: Being Lieutenant William Bligh's Log of the Proceedings of His Majesty's Armed Vessel Bounty in a Voyage to the South Seas, to Take the Breadfruit from the Society Islands to the West Indies, vol 1, London, Golden Gockerel Press, 1937, p 381. 
presence of 'Oro, the god of abundance. In the same spirit, they asked Bligh to inscribe on the back of a canvas the 1789 arrival and departure dates of the Bounty and of the Providence in 1792. Pointe Vénus now boasts a small Captain James Cook memorial, which is visited by tourists from throughout the English-speaking world. Cook's figure has reached such a heroic status that, to many, the British captain could only have been killed by Hawaiians in 1779 because they mistook him for a deity. As proposed by Gananath Obeyesekere in 1992, this form of history writing may tell us more about the West anointing their own deities than anything else. ${ }^{59}$

At Pointe Vénus stands another memorial - a stone erected by the Pitcairn descendants of the Bounty mutineers, featuring carvings of the Bounty and the faces of mutineers Christian and Adam Smith. Here thrives the legend of European romantic rebels who dared confront abusive authority and chose freedom in the Pacific. Bligh, who is not celebrated at Pointe Vénus, has nevertheless reached similarly legendary status, although of a notorious kind. As discussed in Chapters 4, 5 and 6 of this volume, novels and movies have secured Bligh's global reputation as an inordinately cruel and vicious officer. Pointe Vénus is, therefore, also haunted by the legend of this other British captain.

Pointe Vénus was the place where the first missionaries from the freshly created LMS appeared on the Duff on 5 March 1797. The missionaries were bringing dictionaries, compiled for them by Bounty prisoners Peter Heywood and James Morrison, with the purpose of spreading the Gospel. It is not within the scope of this chapter to discuss whether Biblical characters may be said to have legendary status; what cannot be gainsaid, however, is that narratives about a single God, Adam and Eve and their descendants surreptitiously became more widely known throughout Polynesia than indigenous narratives of Hiro. The Bible gradually superseded the traditional Polynesian knowledge that was ritually taught at Te ana-vaha-rau. To this day, the sighting of the Duff in Matavai Bay has been officially celebrated as a holiday in French Polynesia.

At the foot of the Pointe Vénus lighthouse has sprouted one last, utterly spurious, European legend that revolves around Scottish writer Robert Louis Stevenson (one of his Bounty-related fictions is discussed in this

59 Gananath Obeyesekere, The Apotheosis of Captain Cook. European Mythmaking in the Pacific, Honolulu, University of Hawai'i Press, 1992. 
volume, see Naugrette, Chapter 5). A plaque celebrating Stevenson's alleged 'feelings of emotion', as he stood facing the building in 1888, was hung there in 1994. While the quote is apocryphal, ${ }^{60}$ it has further contributed to the displacement of original native heroes like Hiro, and to the influx of Western legends associated with Pointe Vénus. Nowadays, many Polynesian organisations are actively reviving Pointe Vénus as a Polynesian cultural hub.

\section{Polynesian maritime science}

\section{Tupaia, Captain Cook's Tahitian pilot}

What remains of Polynesian maritime science today has partly been transmitted through the notes of European explorers. It is mostly thanks to their written observations and those of the naturalists on board their vessels that Polynesian mastery of the sea can be understood. Tupaia's map provides many valuable clues in this respect. Tupaia himself enumerated 130 islands and Johann Forster identified no less than 84 of them. ${ }^{61}$

After leaving Tahiti, Tupaia wished to visit his relatives once more and he steered James Cook towards the Leeward Islands, which became the explorer's first 'big' Pacific discoveries (Cook was unaware that the Dutch had been there before him). While Cook came to see Tupaia's skills as of use in finding the fabled southern continent, Tupaia was more interested in heading west where, within 10 or 12 days of sailing, several islands he had visited before were located, such as Samoa. He warned Cook that their return voyage north against prevailing winds and currents could take up to 30 days. Cook, however, was intent on abiding by the Admiralty's instructions and headed south regardless. Having discovered nothing of import, except the island of Rurutu (known to Tupaia as Hitiroa), Cook eventually followed Tupaia's advice and veered west in order to reach New Zealand. While he was on board the Endeavour, Tupaia was at all times able to identify the precise direction of Tahiti. On the day before he died in Batavia, he was still pointing at Faupapa, or Sirius, his native island's zenith star, which he proudly named fetù roa, the 'great star'.

60 For information on the design of the Pointe Vénus lighthouse, see Robert Veccella, 'Le phare de la pointe Vénus à Tahiti (1767-1868): 100 ans d'histoire de la baie de Matavai', Masters thesis, Université Bretagne Sud, 2016.

61 Forster, 1996, p 310. 
In 1768, the year before Cook's arrival, Louis-Antoine de Bougainville also noted the proclivities of the Tahitians for navigation: ${ }^{62}$

Finally, this nation's educated people - without being astronomers contrary to our gazettes' claims - have classified the most notable constellations; they know their diurnal motions, and they rely on them to steer their way in the open sea from island to island. With this navigation system, they may lose all sight of land sometimes for more than three hundred leagues. Their compass is the race of the sun during the day, and the position of the stars during the nights, which are almost always beautiful in the tropics. (Bougainville 1982: 266) ${ }^{63}$

However observant, Bougainville chose not to heed the desperate pleas of Aoutourou (Ahutoru), the young Tahitian who agreed to sail under his protection. Aoutourou insisted that Bougainville head for Ra'iatea, his native island, so that he might bid his relatives farewell. Had the French explorer complied, he would have discovered the islands of Huahine, Ra'iatea, Taha'a, Borabora and Maupiti - a privilege that was later bestowed on Cook.

During Cook's second voyage in 1772-74, he and naturalists Johann Forster and his son, Georg, verified the accuracy of Tupaias map by visiting all of the islands that extended from the Marquesas in the east to Fiji in the west. The duration of their stay in Tahiti enabled them to write a valuable 700 -entry dictionary registering 18 th-century Tahitian lexicon. ${ }^{64}$ (Sailing with Cook on his third voyage, William Bligh thus acquired some knowledge of the Tahitian language, which he used to negotiate the Bounty mission in 1788.) The Forsters recorded language wherever they landed and, across the vast ocean area traversed, they discovered that people shared idioms from the same family. Johann Forster even managed to register dialectal differences between Polynesian languages. He found that, in the Society Islands, there were variations between the Leeward Islands (Tahiti) and the Windward Islands (Borabora). Like Cook and

62 Louis-Antoine de Bougainville, Voyage autour du monde par la frégate du Roi, 'La Boudeuse' et la flute 'l'Etoile', Paris, Gallimard, 1982.

63 'Au reste, les gens instruits de cette nation, sans être astronomes, comme l'ont prétendu nos gazettes, ont une nomenclature des constellations les plus remarquables; ils en connaissaient le mouvement diurne, et ils s'en servent pour diriger leur route en pleine mer d'une île à l'autre. Dans cette navigation, quelquefois de plus de trois cents lieues, ils perdent toute vue de terre. Leur boussole est le cours du soleil pendant le jour, et la position des étoiles pendant les nuits, presque toujours belles entre les tropiques' (Bougainville, 1997).

64 KH Rensch, The Language of the Noble Savage, the Linguistic Fieldwork of Reinhold and George Forster in Polynesia on Cook's Second Voyage to the Pacific 1772-1775, Canberra, Archipelago Press, 2000. 
Banks, he also observed the closeness of Maori and Tahitian customs and concluded that these islands were unquestionably interrelated. But, without any instruments of navigation, how could the inhabitants have travelled such long distances?

Two other Europeans of the early contact era spent considerable time in Tahiti: Maximo Rodriguez stayed 10 months at Tautira between 1774 and $1775 ;{ }^{65}$ the Bounty's James Morrison spent a year and a half in Matavai between 1788 and 1791 (before and after the mutiny), and was involved in local shipbuilding. ${ }^{66}$ Their journals are of great ethnographic value, but provide scant detail about Polynesian astronomical science. The journals of Samuel Wallis, Bougainville, Cook and Bligh also lack information on the topic. Reviewed by editors, these journals were at times stripped of information that may have been crucial for reconstructing traditional knowledge. ${ }^{67}$

Few astronomical clues have been handed down via Polynesian oral tradition. While genealogies, myths, fables and legends narrate the voyages of gods and demigods, they fail to offer practical details that align with modern-day scientific standards. When these oral communications are confronted with the testimonies of explorers, however, and when they are examined from a linguistic perspective, they yield highly valuable information.

Most of what is now known about ancient Polynesian astronomy may be traced back to testimonies from the LMS. Reverend John Orsmond's work, in particular, is a major source of information - collected from Tahitian King Pomare II and other witnesses to ancient Tahitian maritime science and astronomy from 1817 onward. Orsmond's original manuscript, which was given to Governor Charles Lavaud and was later lost in Paris, was partially rewritten by Teuira Henry, Orsmond's granddaughter. It was published in English in 1928 under the title Ancient Tahiti, and is particularly valued for its unique collection of Tahitian texts. Henry's censorship of certain aspects of Orsmond's original work resulted from her 'shock [at] pagan practices, especially polytheism, infanticide,

65 M Rodriguez, Les Espagnols à Tahiti (1772-1776), Paris, Société des Océanistes, 1995.

66 James Morrison, Journal de James Morrison, Papeete, Société des Etudes Océaniennes, 1981.

67 Many of these journals are now available online at the National Library of Australia website southseas.nla.gov.au. 
human sacrifice and the exuberance of the time' ${ }^{68}$ Fortunately, this censorship spared the sections of the manuscript that dealt with the less controversial themes of astronomy and navigation.

\section{Europeans navigating with instruments in contrast with Polynesians navigating with stars}

Given what we now know about the ancient Polynesian art of landfinding, to conclude this chapter I briefly compare European and Polynesian navigation skills during the period of early contact with Europeans and around the time of the Bounty events. The aim is to provide a fresh perspective on the Bounty drama and, perhaps, tip the balance of hitherto predominantly Western narratives. The point I would like to make here is that nautical and scientific achievements are not always found where we expect.

During the earliest contact period, European navigators used a range of instruments to determine their courses and positions, including compasses, astrolabes, quadrants and arbalestrilles. In the 18th century, these were superseded by octants and sextants. The magnetic needles of compasses could be trusted to point north. Other instruments would measure how high the sun or stars stood above the horizon, or help them to determine latitudes. This explains why the Spanish and the Dutch, then the English and the French, sailed across the Pacific along imaginary lines parallel to the equator. They would position their ships at a specific latitude and sail on, making sure that they held their course. Whenever they found an island they reported its latitude. The only means for them to locate that island again was to retrace their course along the same latitude and trust their luck, which often proved fickle because of the limitations of their instruments and the inconsistent accuracy of existing navigational records.

68 '... choquée qu'elle fut des pratiques païennes et en particulier par le polythéisme, l'infanticide, les sacrifices humains et l'exubérance des mœurs de l'époque' (Alain Babadzan, Mythes Tahitiens, Paris, Gallimard, 1993, p 10). 
Longitudes were even more difficult to measure. Contrary to latitudes, which could be referenced in relation to the equator and the poles, longitudes have no natural bearings and are calculated through angular 360-degree measurements based on reference meridians. Europeans were desperate to invent a precise and sturdy clock able withstand the hazards of sea voyaging, and whose measurement of time would be independent enough from geographical locations. This was finally achieved in England in 1734 (see Young, Chapter 7). Before then, European explorers could only estimate the distance travelled since leaving port in order to attempt to calculate an island's longitude. The margin of error was such that locating an island on a subsequent voyage was virtually impossible. This problem was not remedied until the English sailed into the Pacific.

Polynesians had worked things out in their own way, without instruments. Tahitians could navigate without instruments because they had conceived of pillars and star trails. Those pillars and star trails were stored within the myth of the 'Birth of celestial bodies', a myth that has only recently been reconstructed. ${ }^{69}$ For Polynesians, there were two kinds of stars by which they could navigate. The first were stars that would endlessly emerge from specific 'wells' located below the horizon, and would then draw a rua (star trail), across the sky; there were a dozen such stars, each recognisable by means of a ta'urua star. On the other hand, there were stars that positioned themselves one after the other high in the sky; these successive positionings would make a pou (meridian/pillar) that could be referenced to another star north or south. A dozen such stars were identified, each recognisable by means of an 'ana star.

By memorising their positions from the zenith stars, Polynesians could return to locations at any time. They were able to locate an island from any location within the Pacific, as Tupaia demonstrated to the British in Batavia.

\section{Navigating with the environment}

Navigating with stars may have been efficient, but it was not sufficiently accurate to give a focal range greater than about 170 nautical miles, or 315 kilometres. With this method alone, it was all but impossible

69 Jean-Claude Teriierooiterai, 'Mythes, astronomie, découpage du temps et navigation traditionnelle: l'héritage océanien contenu dans les mots de la langue tahitienne', $\mathrm{PhD}$ thesis, Université de Polynésie française, 2013. 
to find a particularly remote island such as Pitcairn. Pacific Islanders, however, had a raft of additional devices and data to refine their voyaging and become more accurate at targeting particular islands. These devices and data were found in their environment, and the methods of deciphering them have been closely studied and tested by David Lewis. ${ }^{70}$

One of the navigation devices used by Polynesians was to expand targets by aiming at a group of islands instead of a single island. Beyond a 25- or 30 -nautical-mile radius, a high island is not visible from the open sea. Groups of islands expand the radius through addition or overlapping, and therefore expand the target area. Once a group of islands was reached, it was not difficult to navigate to other islands within the group. For instance, from Tahiti, it was easier to reach Hao, in the centre of the Tuamotu Islands, by navigating towards the archipelago as a whole. North to south, the Tuamotu Islands extend over 1,500 kilometres, whereas Hao is only about 30 kilometres wide. With a few exceptions, the islands of the Pacific cluster into archipelagos, making this navigational technique effective across the region.

A second device used by Polynesian navigators was observation of the ocean's hues. The ocean's colours vary according to depth and the lighter coloured deep reefs in the middle of the oceans are excellent markers for navigation. Reefs close to an island or archipelago indicate the sailing distance required before reaching a target.

Flotsam was also used as navigational devices. At sea, flotsam is ferried from land by currents and provides clues regarding the distance from its destination. For instance, a dry coconut drifting with the current can be assessed in terms of the sourness of the coconut water, or the degree to which the sinnet is soaked. Both of these factors indicate the length of time that the coconut has been at sea and, depending on the speed of the current, how far it has drifted from land. The same method was applied to coconut fronds and other plant debris.

70 David Lewis, We, the Navigators: The Ancient Art of Landfinding in the Pacific, Honolulu, University of Hawai'i Press, 1972. 
Another landfinding device was to observe the swell. A swell that meets no obstacle will remain steady. Any obstacle will send a reflected secondary swell or will alter its shape, bending it near the coast or causing turbulence in the rear. Depending on the shape of the swell, navigators could locate an island even before they could see it.

Polynesians could identify atolls by the colour of the clouds above them. The lagoons of some atolls can shine so brightly that their colour reflects on the clouds above. This phenomenon is called paku in the Tuamotu Islands and $p a^{c} u$ in Tahiti; hence the name Pa'umotu given by Tahitians to the archipelago in the past and to its inhabitants today. The reflection of the lagoon around 'Anaa is particularly spectacular; being so bright that it can be sighted from over the horizon.

Polynesians would also look for cumuli cloud formations generated by the heat of high islands, or large clouds that cling to island peaks and hang still over a landmass. The presence of a stable cumulus cloud formation amidst otherwise moving clouds indicates a landmass.

The flight of birds and their flying range also gave navigational clues in that some sea birds leave land in the morning to reach their fishing grounds and fly back at night. Their morning and evening flight paths therefore point to islands, and even provide some indication of how far away those islands may lie. Some species, like phaetons, fly within a range of approximately 170 kilometres and sighting one suggested an island lay somewhere within that distance.

It is possible that some of these indigenous navigation methods were familiar to Europeans before they sailed into the Pacific. Tropical island environments had been known to the Spanish since the voyages of Christopher Columbus, and the Spanish were already familiar with sailing in the Caribbean and the Indian Ocean as far as the Philippines. The Dutch owned outposts in the Caribbean and Indonesia, so they were also used to navigating tropical island regions.

It was not until the voyages of Jose de Andia y Varela and James Cook that the Europeans expressed any interest in Polynesian navigation. Puhoro educated the Spanish as to how Tahitians used the wind as a compass, while Tupaia taught the British how to read clouds, winds and stars for direction and weather forecast. Mahine, who embarked with Cook on his second voyage, used bird flight to calculate the distance of an island. On Cook's third voyage, Tahitian Ma'i (Omai) returned home on the 
Resolution - William Bligh was mate on this voyage. It was not reported whether Bligh and Ma'i spoke during the journey, but they are bound to have done so at some point given the length of the voyage. Ma' $i$ was not a navigator and nor was he as knowledgeable as the other indigenous travellers but, like all Polynesians, he would have been a fisherman and therefore able to share the basics about sailing.

Cook interacted with Polynesians often enough to integrate the Polynesian navigating methods of Tupaia, Mahine and Ma'i into his own voyages. Bligh, in turn, was able to observe Cook's methods. While Bligh's notes on Tahitian customs and language are valuable - for example, he was the first to notice the taboos applied to the syllables that made up the name of a ari $^{\prime} i$ and that, once Pomare became king of Tahiti, the words po and mare were banished from everyday language, and replaced by hota and ru $i$ - he did not include specific observations about the Polynesian arts of navigating and landfinding.

Bligh's concern for the health and wellbeing of the Bounty crew was largely misconstrued as harshness. The lessons he learned from Cook about navigating in the tropics, however, saved his life and those of his men. On the Bounty long boat that took him 3,620 nautical miles (6,700 kilometres) from Tonga to Timor, Bligh followed the same latitude up to Australia, like Polynesians using rua. Indeed, he may have relied on Polynesian expertise in making allowance for 'leeway, effect of currents and the speed made through the water', since the charts he produced from his surveys on the Bounty launch turned out to be 'considerably more accurate for scale and orientation than Cook's' ${ }^{71}$

\section{The untimely demise of the Polynesian art of navigation caused by the influx of Europeans}

After James Cook, the number of European visitors to the Pacific increased and with them came another way of looking at the sky. Venus lost her poetic name, Ta'urua-nui-horo-ahiahi ('Great-celebration-that-runs-in-theevening'), and it was replaced by Venuti, a phonetic adaptation of Venus into Tahitian. Ta'urua-nui-i-tu'i-i-te-pōrou-o-te-ra'i ('Great-celebration-that-

71 ACF David, 'The Surveyors of the Bounty: A Preliminary Study of the Hydrographic Surveys of William Bligh, Thomas Hayward and Peter Heywood and the Charts Published from Them', Royal Navy Hydrographic Department, Ministry of Defence, Taunton, Somerset, 1982, p 23, quoted in Salmond, 2011, p 225. 
hits-the-zenith-of-the-sky') became simply Iupiti, a rendering of Jupiter. Sirius, which was paramount to Tahitians because it shone at their island's zenith, was known as Ta'urua-faupapa ('Celebrations-of-the-first-greatleaders') until it disappeared altogether from the Tahitian lexicon and, it might be said, from the Tahitian sky.

Between 1822 and 1840, Louis Isidore Duperrey, ${ }^{72}$ Jules Dumont d'Urville, ${ }^{73}$ François-Edmond Pâris $^{74}$ and René Primevère Lesson ${ }^{75}$ lamented the decline of Polynesian navigation and the disappearance of Ari' $i$ Tü's fleet of double canoes, which had been so fervently praised by Cook in 1774. Pâris, who sailed with Dumont d'Urville on the Astrolabe in 1826-29, made an inventory of Tahitian canoes. He wrote this bitter note:

We took advantage of our long stay with them to have a look at the canoes; all the large ones were extinct, but we are glad that we could find the detailed drawing of one from Captain Cook's second navigation as he witnessed the gathering of a whole fleet, which may give a favourable impression of what Taïti (Tahiti) used to be like, in those days. ${ }^{76}$

Pâris' drawing of a contemporary canoe reveals that its appearance had changed from the ancient $v a^{\zeta} a$ and it was now constructed as a hybrid of traditional canoes and certain recently introduced European boats. A sailing sprit had replaced the bird wings that once characterised Tahitian $v a^{\prime} a$ with a triangular sail. Lesson, surgeon on board Duperrey's Coquille during the 1822-25 scientific circumnavigation, had a few years earlier bemoaned the Tahitian neglect of the art of shipbuilding:

72 Louis Isidore Duperrey, Voyage autour du monde: exécuté par ordre du roi, sur la corvette de $S a$ Majesté, la Coquille, pendant les années 1822, 1823, 1824 et 1825, Paris, Arthus Bertrand Libraire Editeur, 1826.

73 Jules Dumont d'Urville SC, Voyage pittoresque autour du monde, Papeete, Haere Po No Tahiti, 1988.

74 E Pâris, Essai sur la construction navale des peuples extra-européens ou collection des navires et pirogues construits par les habitants de l'Asie, de la Malaisie, du Grand océan et de l'Amérique dessinés et mesurés pendant les voyages autour du monde de l'Astrolabe, La Favorite et l'Artémise, Paris, Arthus Bertrand, 1841. 75 RP Lesson, Voyage autour du monde entrepris par ordre du Gouvernement sur la Corvette La Coquille, Paris, Pourrat Frères, 1839.

76 'Le long séjour que nous fìmes parmi eux put être utilisé pour les pirogues; toutes les grandes ont disparu, mais nous sommes heureux d'en trouver un plan exact dans le second voyage du capitaine Cook, qui vit réunie une flotte propre à donner une idée avantageuse de ce qu'était alors Taïti (Tahiti) ...' (Pâris, 1841, p 32). 
One of the arts that modern Tahitians seem to be dropping is that of nautical architecture. Their fertile topsoil has made it less necessary for them to go sailing. These islanders, however, have a perfect knowledge of the islands which surround them on all sides, and which they used to sail to more often, either as friends or foes. The early navigators who landed the Society Islands have left us prints of canoes decorated with very ornate iconic carvings, which are nowhere to be found nowadays. ${ }^{77}$

European-style boats now sailed between islands. The use of compasses, stopwatches, octants and sextants put an end to a 2,000-year-old navigational practice. All that was left for Polynesians were their reminiscences, transmitted in the form of glorifying myths and legends that recounted the great deeds of their epic heroes.

Another unfortunate consequence of the upheaval of this contact period was the extinction of Tahitian astral calendars. Calendars showed how Tahitians had solved the crucial problem of fitting together lunar months and natural cycles. They determined rituals that anticipated the first ' $u r u$ harvests and the first bonito fishing parties. Three stars would successively come into play at different times in the year to synchronise lunar months with seasons: Rea, the sun at solstices and equinoxes; Matari ${ }^{~} i$, the Pleiades at their evening heliacal rise before the start of the austral summer and their evening heliacal setting before the start of the southern winter; and Rehua, Pollux, at its heliacal evening setting. It may be reasonably argued that Tahitians had developed elaborate concepts about time and astral movements. The only remnant of Polynesian calendrical systems today is a lunar calendar used by fishermen and farmers.

Traditional Tahitian culture collapsed in the early 19th century, along with traditional forms of astronomy. European voyagers have even wondered whether Polynesians ever had any such science, despite there being no other way to account for the settlement of Polynesia, located 6,000 kilometres from the nearest continent. Jacques Antoine Moerenhout, ${ }^{78}$ who did not think highly of the Islanders' sailing skills in the 1830s, wrote that they

77 'Un des arts que les Tahitiens modernes semblent négliger est celui de l'architecture nautique. La fertilité de leur sol leur a rendu moins nécessaires les navigations lointaines. Ces insulaires, cependant, ont une parfaite connaissance des îles qui, de toutes parts, les entourent, et qu'ils visitaient plus fréquemment autrefois, soit comme amis, soit comme ennemis. Nous voyons en effet, dans les gravures que nous ont laissées les premiers navigateurs qui abordèrent aux îles de la Société, les pirogues ornées de sculptures emblématiques très soignées, dont on ne découvre nulle trace en ce moment' (Lesson, 1839, pp 386-87).

78 Jacques-Antoine Moerenhout, Voyages aux îles du grand Océan, 2 vols, Paris, Adrien Maisonneuve, 1837. 
were incapable of sailing from one island to the next without European support. He suspected, however, that Tahitians were the heirs of a brilliant civilisation:

First, I am convinced that, at the time when they were discovered by Europeans, Polynesian people had reached a state of absolute decadence. Second, I believe that prior to that discovery, probably from a very early date and over a certain period of time, they may have gone through a stage of civilization and relatively advanced political splendour. ${ }^{79}$

He further declared:

To me, it cannot be gainsaid that Polynesians went through a second stage when, to some extent, they practised arts, sciences and navigation. This may have lasted for quite a while in some islands, before it gradually changed to the situation I have mentioned before. ${ }^{80}$

Not unlike Reverend William Ellis, who thought that Tahitians might have originated from Mount Meru in India, Moerenhout speculated that the original land of their civilised noble ancestors was part of a sunken continent lying deep down on the ocean floor. To him, contemporary Tahitian people were merely survivors of a decadent culture.

Moerenhout was in touch with Reverend John Orsmond and relied heavily on Ancient Tahiti in writing up his research as $A$ Voyage to the Great Ocean Islands. Not being a missionary, he was not burdened with Orsmond's moral qualms about Tahitian culture. Despite not being proficient in Tahitian - neither written or spoken - and even though his Tahitian quotes are incomplete, his interpretation of Tahitian ways of life were less subject to religious prejudice and were, in the fields of spirituality or morality, more explicit than Orsmond's. ${ }^{81}$ His description of Tahitian calendar rituals, for example, is central to our modern understanding of traditional Tahitian year divisions.

79 'Je suis convaincu d'abord, que les peuples de la Polynésie étaient, à l'époque de leur découverte par les Européens, dans un état de décadence absolue. Je crois en second lieu, qu'antérieurement à cette même découverte, ils ont dû, pendant plus ou moins longtemps, et, probablement depuis une époque déjà fort ancienne, connaître un état de civilisation et de splendeur politique relativement très avancé' (Moerenhout, vol 2, 1837, p 176).

80 'Il me paraît donc certain qu'il y a eu une seconde époque pendant laquelle les Polynésiens cultivaient jusqu’à un certain point les arts, les sciences, et se livraient à la navigation. A cet ordre de choses, qui a dû se prolonger beaucoup dans quelques-unes des îles, aura insensiblement succédé celui dont j'ai parlé' (Moerenhout, vol 2, 1837, p 219).

81 Moerenhout, vol 2, 1837, p 11. 
Although other missionary narratives from the same period may be of great value, they include few Tahitian writings. Their authors mostly provided their own translations, which they adapted to suit their religious views. For example, Ellis, provides a detailed description of Tahitian customs. However, the reliability of his work cannot be ascertained, as the original Tahitian texts are not referenced. Of particular interest here, however, is Ellis' description of a personal experience during a voyage between Tahiti and Huahine in 1820, when his companions relied on Tahitian navigation methods using the stars:

The natives of the islands were, however, accustomed in some degree to notice the appearance and position of the stars, especially at sea. These were their only guides, in steering their fragile barks across the deep. When setting out on a voyage, some particular star or constellation was selected as their guide in the night. This they called aveia ['avei'a], and by this name they now designate the compass, because it answers the same purpose. The Pleiades were favourite aveia with their sailors, and by them, in the present voyage, we steered during the night. ${ }^{82}$

This document shows that, in the 1820s, Tahitians could still read the stars, and used them to sail between the Society Islands. Sailing was not just instinctive, but based on firm empirical knowledge. Polynesian navigators understood the complexities of star motions, and climatic, ecological and biological cycles.

\section{Conclusion}

This chapter has contextualised the Bounty from the Polynesian side of the beach, focusing on traditional Pacific maritime culture. Its survey of a series of early encounters with Europeans accounts for the ways that Europeans were received by Pacific Islanders between the 16th and 18th centuries, including the contrasting receptions given to William Bligh and Fletcher Christian in Tahiti, Tonga and Tubua' $i$. The particular emphasis of this chapter on pre-contact inter-island connections paves the way for the detailed archaeological, historical and cultural study of pre-contact Pitcairn in the chapter that follows (see Molle \& Hermann, Chapter 2).

82 William Ellis, Polynesian Researches, During a Residence of Nearly Eight Years in the South Seas Islands, vol 2, Newgate, Fisher, Son, \& Jackson, 1928, p 412. 
Since most Bounty narratives extoll the achievements of British navigators - and deservedly so - in this chapter it has been my humble purpose to draw contrapuntal attention to the outstanding navigational expertise that Polynesians developed and perfected over many generations before Europeans arrived. It is unlikely that the Tahitians who sailed with Christian to Pitcairn were well versed in navigation, as it seems that there were no tahu' $a$ on board. An expert fa' atere va' $a$ might have steered the Bounty to a more appropriate island, such as any of the other three in the Pitcairn group, which were more welcoming, had been recorded in myths and were reported on Tupaia's map. ${ }^{83}$ It should be noted, however, that around 1794, in the spirit of their valiant ancestors, many of the Bounty Tahitian women in Pitcairn took to the sea on their own, in an attempt to escape from Pitcairn on a boat that, being leaky, sank off the coast.

In pre-contact times, while there was some variation between the navigation concepts and methods developed in each Polynesian archipelago, there was also remarkable similarity in the techniques used across the region. With European intrusion, these techniques were rapidly lost, as was the technique for building large double canoes. Europeans brought with them a new navigation system based on highly developed mechanical instruments, and they introduced a new form of single-hulled vessel. Star navigation expertise was lost for several generations. Oral transmission of traditional navigation methods was disrupted and the introduced religions strove to ban the traditional rituals and chants that accompanied the myths associated with navigation, and the local terms that conveyed scientific concepts.

It appears that none of the elements of Polynesian navigation expertise have survived. Nowadays, most Tahitians are unaware of the skills of their forebears. They find it hard to believe that their ancestors had managed to traverse such vast ocean distances and that their scientific approach to astronomy, navigation and time division was so refined. Modern navigation methods using a sextant, the measurement of angles and ephemeris, rendered traditional navigation methods obsolete. Simpleto-use Western calendars and the introduction of Christian religions led to the replacement of the Tahitian calendar that was founded on lunar and astral cycles.

83 The British knew that those islands existed but they did not know where they were. 
There was no other way for Polynesians to exchange with their neighbours but to master the ocean. They achieved this through the interpretation of astronomical and natural phenomena. The traditional navigation skills of these people, who have been thought of as 'little', are unrivalled. In addition to their ability to read the signs of their environment, the genius of Polynesian navigators lay primarily in their understanding of celestial movement. Developing a system of celestial pillars and star trails made them genuine astronomers. The stars were an integral part of their lives. Their deified ancestors had themselves grown into stars, and thus, their relationship to the stars was extremely intimate. While Polynesians may not have known how to write, they certainly knew how to read their natural environment. 
This text is taken from The Bounty from the Beach: Cross-Cultural and Cross-Disciplinary Essays, edited by Sylvie Largeaud-Ortega, published 2018 by ANU Press, The Australian National University, Canberra, Australia. 